\title{
Elephant Elephas maximus Linnaeus (Proboscidea: Elephantidae) migration paths in the Nilgiri Hills, India in the late 1970s
}

\author{
E.R.C. Davidar ${ }^{1}$, Peter Davidar ${ }^{2}$, Priya Davidar ${ }^{3}$ \& Jean-Philippe Puyravaud ${ }^{4}$ \\ ${ }_{1}^{1}$ Deceased. \\ ${ }^{2,4}$ ECOS, 9 A Frédéric Ozanam St., Colas Nagar, Puducherry 605001, India \\ ${ }^{3}$ Department of Ecology and Environmental Sciences, Pondicherry University, Kalapet, Puducherry 605014, India \\ Email: ${ }^{2}$ sigurnaturetrust@gmail.com, ${ }^{3}$ pdavidar.ees@pondiuni.edu.in, ${ }^{4}$.jp.puyravaud@gmail.com (corresponding author)
}

Date of publication (online): 26 November 2012 Date of publication (print): 26 November 2012 ISSN 0974-7907 (online) | 0974-7893 (print)

Editor: Heidi Riddle

\section{Manuscript details:}

Ms \# 03008

Received 15 November 2011

Final received 31 August 2012

Finally accepted 15 October 2012

Citation: Davidar, E.R.C., P. Davidar, P. Davida \& J.-P. Puyravaud (2012). Elephant Elephas maximus Linnaeus (Proboscidea: Elephantidae) migration paths in the Nilgiri Hills, India in the late 1970s. Journal of Threatened Taxa 4(14): $3284-3293$

Copyright: () E.R.C. Davidar, Peter Davidar, Priya Davidar \& Jean-Philippe Puyravaud 2012 Creative Commons Attribution 3.0 Unported License. JoTT allows unrestricted use of this article in any medium for non-profit purposes, reproduction and distribution by providing adequate credit to the authors and the source of publication

Author Details, Author Contribution and Acknowledgements: see end of this article.

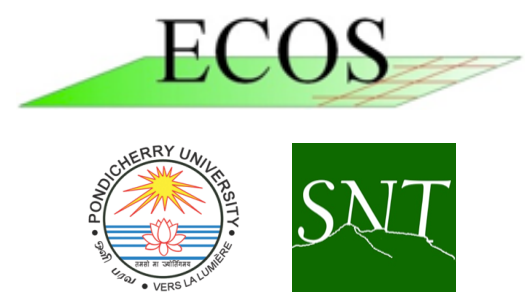

urn:Isid:zoobank.org:pub:8DBD3959-302443AE-938E-EA234D2852B0

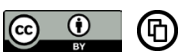

OPEN ACGESS | FREE DOWNLOAD
Abstract: The study presented was carried out in 1978 with the support of the Asian Elephant Specialist Group (AsESG) of the International Union for the Conservation of Nature (IUCN) Species Survival Commission (SSC). Its objective was to investigate the impediments to elephant movement in the Nilgiri Hills, in the Western Ghats of India, in an attempt to suggest positive steps to encourage movement through the provision of corridors. The report was left unpublished, but given its importance as a reference document for the conservation of the Asian elephant in the Nilgiris, in 2011 the last two authors decided to publish it. The process of habitat fragmentation has been going on ever since man started agriculture. But this problem has, of late, become much more acute due to mounting pressure on land. The corridor concept applied to wildlife is the provision of a free and, as far as possible, unimpeded way for the passage of wild animals between two wildlife zones. A corridor's more important function is to prevent wild animals from getting isolated in small pocket-like islands. Maintaining elephant habitat connectivity in and around the Nilgiris rests upon the understanding that elephant populations of the several protected areas of the now Nilgiri Biosphere Reserve must remain active. The first author surveyed the Nilgiris on foot and on elephant back for several months in 1978. It was concluded that four areas (the Nilgiri north slopes and Deccan Plateau, the south and southeastern slopes, the Gudalur Plateau, and the upper plateau) harboured together 10 corridors that needed to be maintained, or restored, or even partially restored.

Keywords: Asian Elephant, connectivity, conservation, corridors, Elephas maximus Linnaeus, habitat, Nilgiri Biosphere Reserve.

\section{PREFACE}

The work presented here was undertaken by the late E.R.C. Davidar for the International Union for the Conservation of Nature (IUCN) Asian Elephant Specialist Group (AsESG) in the second half of the 1970s. The study was promoted by the late Mr. J.C. Daniel, former Chairman, IUCN AsESG, and former Vice-President of the Bombay Natural History Society (BNHS).

Forty years ago, naturalists started to be concerned about Asian Elephant Elephas maximus migrations. Nothing much was known about it but biologists could see that development in the Nilgiri Mountains (Western Ghats of India) posed more and more obstacles to the free movement of elephants. Geographic information systems (GISs) were in their infancy, the Landsat satellite program had just started, and personal computers were rare. In order to visualize how elephants migrated, there was no other way than to go to the field, observe and produce maps, as were doing land surveyors.

Only few people were interested in spending months in jungles 
"infested" (the term used at that time) by dangerous wildlife. E.R.C. Davidar was one of them and had already done extensive field surveys all over the Western Ghats and the Nilgiris (e.g. Davidar 1978). With 25 years of experience in this rough terrain, he walked or visited on elephant back all habitats he thought were of importance.

E.R.C. Davidar finalized the first version of his text "Investigation of elephant migration paths in the Nilgiri Hills and inquiry into impediments to the free movement of elephants and recommendations for the provision of corridors for their movement" in 1981, and submitted it to Mr. J.C. Daniel for comments. The study remained a poorly circulated, unpublished draft. After seeking permission from the IUCN AsESG and the BNHS in 2011, the two last authors decided to publish the report.

Why should we publish an old report as wildlife science in India has considerably evolved since the seventies? There were several reasons. Firstly, it was the first study of elephant corridors in India. Due to the amazing field experience of the lead author E.R.C. Davidar, a life-time of treks and interaction with shikaris (guides of hunting parties) who had an intimate knowledge of the jungle, he came to draw general patterns of elephant migrations in the Nilgiris. The report is consequently a historical record of elephant movements, and an invaluable baseline scenario for any study on corridors for this region. Secondly, it is referred to in technical surveys (Menon et al. 2005), Forest Department master documents (Tamil Nadu Forest Department, 2009), newspapers ${ }^{1}$, scientific articles (i.e. Johnsingh \& Williams 1999), and books (i.e. Santiapillai \& Jackson 1990), but available to only a handful of specialists. Thirdly and most importantly, E.R.C. Davidar understood that his mission of recording corridors was "a purely negative exercise", and extended the scope of the study. His reasoning was that focusing on functional elephants corridors was biased since it would not take into consideration corridors that were recently lost at the time of the study, which has implications for conservation. These lost corridors needed to be restored to reduce conflict with elephants and to properly manage elephant populations. Following this rationale, he recorded

${ }^{1}$ http://www.tehelka.com/story_main49.asp?filename= Ne3000411Corridor.asp functional corridors and also added what he knew to be recently lost major elephant corridors.

Corridors, in his view, were meant to maintain connectivity among core habitats and were necessary (i) outside protected areas, or (ii) within a potentially threatened protected area. To him, it was obvious that particular former passages had to be restored because they were, and still are, potential areas for human / elephant conflict. If restoration was impossible, it was still of value to note the place of a former corridor, because future generations might be more sensitive to the fate of the elephants than ours.

The reader must be warned that the manuscript and study styles are very much at variance with present-day scientific articles. Moreover, the content of the original draft report has been shortened. The text has been edited only when minor changes regarding the expression were absolutely necessary. Recommendations are unchanged. Location names have been retained as per the draft. For example, "Mudumalai Wildlife Sanctuary" was kept instead of "Mudumalai Tiger Reserve", as it is called today. No actualized literature has been added except in the preface. Wherever text has been added in 2011, it is in between brackets [ ].

\section{INVESTIGATING ELEPHANT PATHS IN THE NILGIRIS}

The Nilgiri Hills, located between $11^{0} 10^{\prime}-11^{0} 30^{\prime} \mathrm{N}$ $\& 76^{0} 25^{\prime}-77^{\circ} 00^{\prime} \mathrm{E}$, are an off-shoot of the Western Ghats where the Eastern Ghats terminate. The geographical area of the Nilgiri District is $2,452 \mathrm{~km}^{2}$, and the area covered by this report including forests in Kerala and the Coimbatore District in Tamil Nadu, is $3,000 \mathrm{~km}^{2}$ approximately (Image 1). This region encompasses several forest types, which are mostly tropical wet evergreen, tropical semievergreen, tropical moistdeciduous, and montane wet temperate types of forests (Champion \& Seth 1968). This region is served by both the south-west and northeast monsoons, but there is considerable variability in rainfall and temperature in the different areas since elevation ranges between 200 and 2,600 m.

Elephants are great wanderers. In Africa, elephants Loxodonta africana have been known to cover great distances, and their wanderings have been recorded 


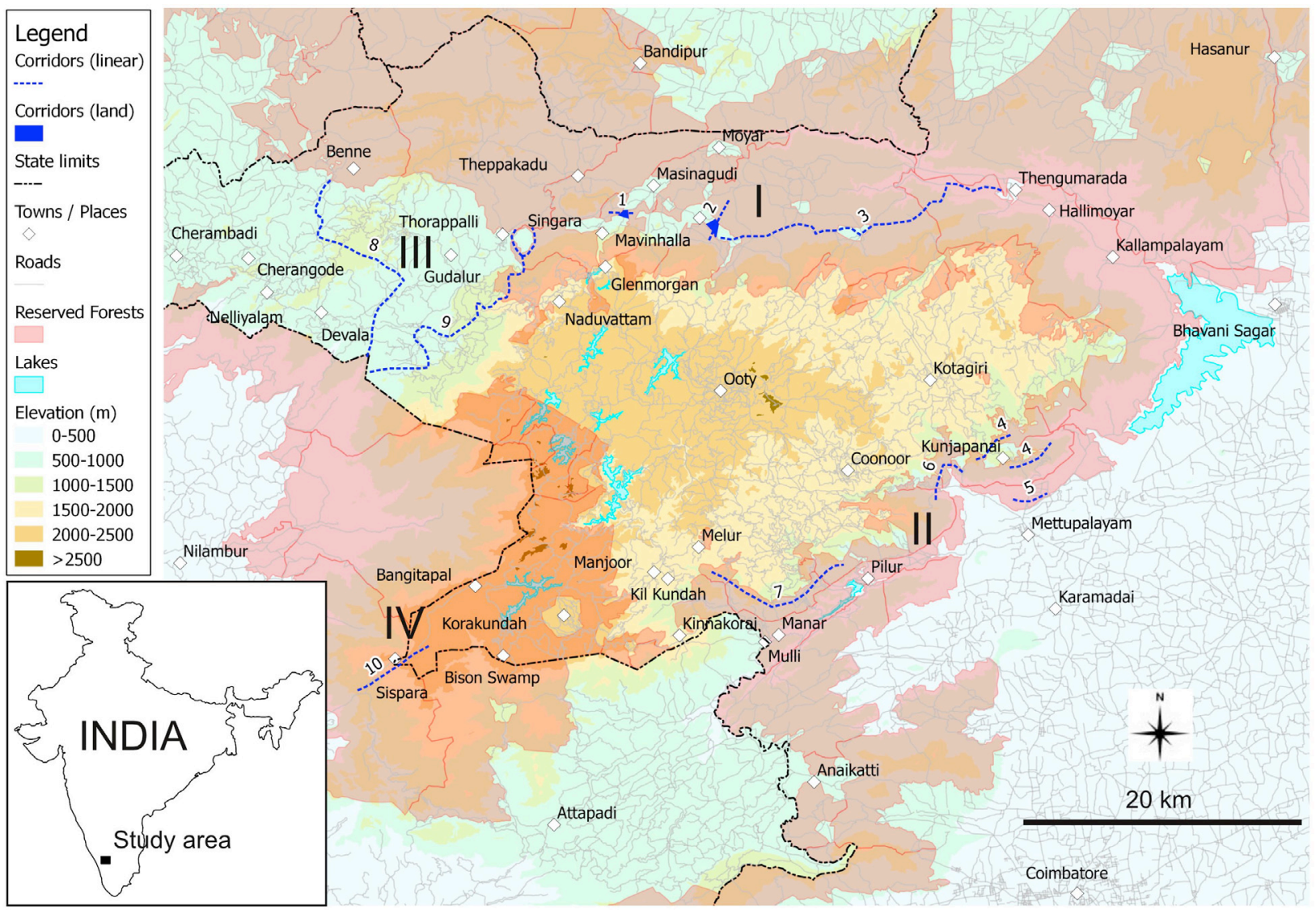

Image 1. Study area with the 10 reported corridors (see text for details) and the four regions in which ecosystem connectivity was severed or under threat: (I) the northern slopes and the southern portion of the Deccan Plateau, (II) the south and south-eastern slopes, (III) the Gudalur plateau, and (IV) the upper plateau

with meticulous care by researchers. There are few such records for the Asian elephants, although migrations, though not on a similar scale as in Africa, do occur. In the Nilgiris, unlike in most places, there is scope for both lateral as well as vertical movement. There also appears to be definite migratory seasons, although solitary bulls as well as bull parties are on the move year round.

These migrations are likely to offer elephants a change of diet and climate. For instance, elephants move from wetter tracts such as tropical wet evergreen and tropical semievergreen forests in the west, to tropical moistdeciduous and dry deciduous scrub in the east. That way, they may escape insects that swarm the wet regions during the south-west monsoon. It also gives sections of the habitat a chance to recover. Wild elephants had their traditional migration paths particularly over difficult hill country. It is believed that engineers opening up the hills to traffic followed some of these trek routes to lay roads as they found that the elephants had done their gradient survey for them! Elephant depredations and damage to crops are less concentrated due to such movement. Encouraging movement of wildlife is a necessary tool in wildlife management.

As the Nilgiri Hills developed, the migration paths began to shift. In the course of time many had to be abandoned due to being cut up by roads, settlements, cultivation, plantations, hydroelectric projects, and so on. Most have ceased to exist. On level ground however, elephants had no set routes, except at river fords and like. In the Nilgiris, short stretches of wellbeaten elephant trails still exist, especially on the slopes.

The present project started as an "Investigation of the migration routes of elephants in the Nilgiris". As the investigation proceeded, it became apparent that it would be a purely negative exercise [as with development, some of these routes had already been severed]. It was, therefore, decided to enlarge the 
scope of the project. In addition, we investigated the impediments to elephant movement in the area to suggest positive steps to encourage movement through the provision of corridors.

The corridor concept applied to wildlife is the provision of a free and, as far as possible, unimpeded way for the passage of wild animals between two wildlife zones. A corridor's more important function is to prevent wild animals from getting isolated in small pocket-like islands. The process of habitat fragmentation has been going on ever since man started agriculture. But this problem has, of late, become much more acute due to mounting pressure on land.

What should be the optimum size of a corridor? The length will naturally depend on the distance to be connected. In doing so, it may become necessary to take a circuitous route connecting existing jungles. There cannot be any hard and fast rule on the width. It may be anything from approximately $100 \mathrm{~m}$ to approximately $2 \mathrm{~km}$. The wider the better. But limitations such as the lay of the land, the types of country, and practical consideration such as causing least disturbance to people who are likely to be affected by the provisions of corridors has to be taken into account in determining the width.

\section{METHODS}

Wildlife literature relating to the Nilgiris was exhaustively researched for information [in 1978] on elephants' migration and to identify migration paths. Unfortunately references on the subject were sketchy [at the time of this report]. All known elephant habitats were extensively covered on foot following migration paths whenever possible.

Four areas seemed of particular importance, so we divided the Nilgiris into four broad sections: (I) the northern slopes and the southern portion of the Deccan Plateau (called "Deccan Plateau" hereafter), (II) the south and southeastern slopes, (III) the Gudalur plateau, and (IV) the upper plateau. [All corridors noted 1 to 10 in the four different areas were represented in Image 1. In the original report, corridors were marked on photocopied survey of India topographic maps. These documents would have been adequate forty years ago when forest officers knew the area well. These original maps were used to produce more readable documents. Reserved forest layers have been redrawn on the basis of Prabhakar \& Pascal (1996) with GRASS-GIS (2011) and QGIS (2011). The reserved forests approximately represent the elephant habitat. Most of the reserved forests could be represented fairly accurately except the northern Attappadi Reserved Forest, which was improperly delimited.]

\section{RESULTS}

\section{Nilgiri north slopes and Deccan Plateau}

This region is defined as the section of the Deccan Plateau north of, and below the main Nilgiri Plateau towards the east of the Mudumalai Wildlife Sanctuary (Image 2). Reserved forests of the Sigur range occupy most of the land area. Interspersed among these reserved forests are the populous village of Masinagudi, some hamlets, tribal settlements, Electricity Board camps, and cattle pens besides cultivated 'patta' lands. There are also some revenue forests and revenue lands belonging to the State Government and private forests. Some of these non-reserved forests serve as links between reserved forests.

This region, the slopes of the main Nilgiri range as well as the slopes leading down to the Moyar River in the north, supports a fair elephant population. The most important function of this area is that it serves as the migration route between Mudumalai and the Wyanad forests on the west, and the Talamalai/Hasanur Plateau and Biligirirangan ranges on the east and northeast.

Obstructions to free movement of elephants occur in the shape of penstocks (huge cylindrical pipes) and trolley lines leading to the Singara and Moyar power houses and the flume channel connecting the two, and 'patta' lands. In spite of these obstructions elephants trek from one section to the other using interspersed private forests and revenue forests. It is essential that these non-reserved forests should be preserved to facilitate elephants and other animals to trek from one section to the other avoiding long detours.

\section{The Mudumalai-Singara-Sigur connection}

Glenmorgan, on the edge of the upper Nilgiri slope, is where the head works of the Singara power house is located. Along the entire width of this $1,000 \mathrm{~m}$ slope, at the foot of which the Singara power house is installed, 


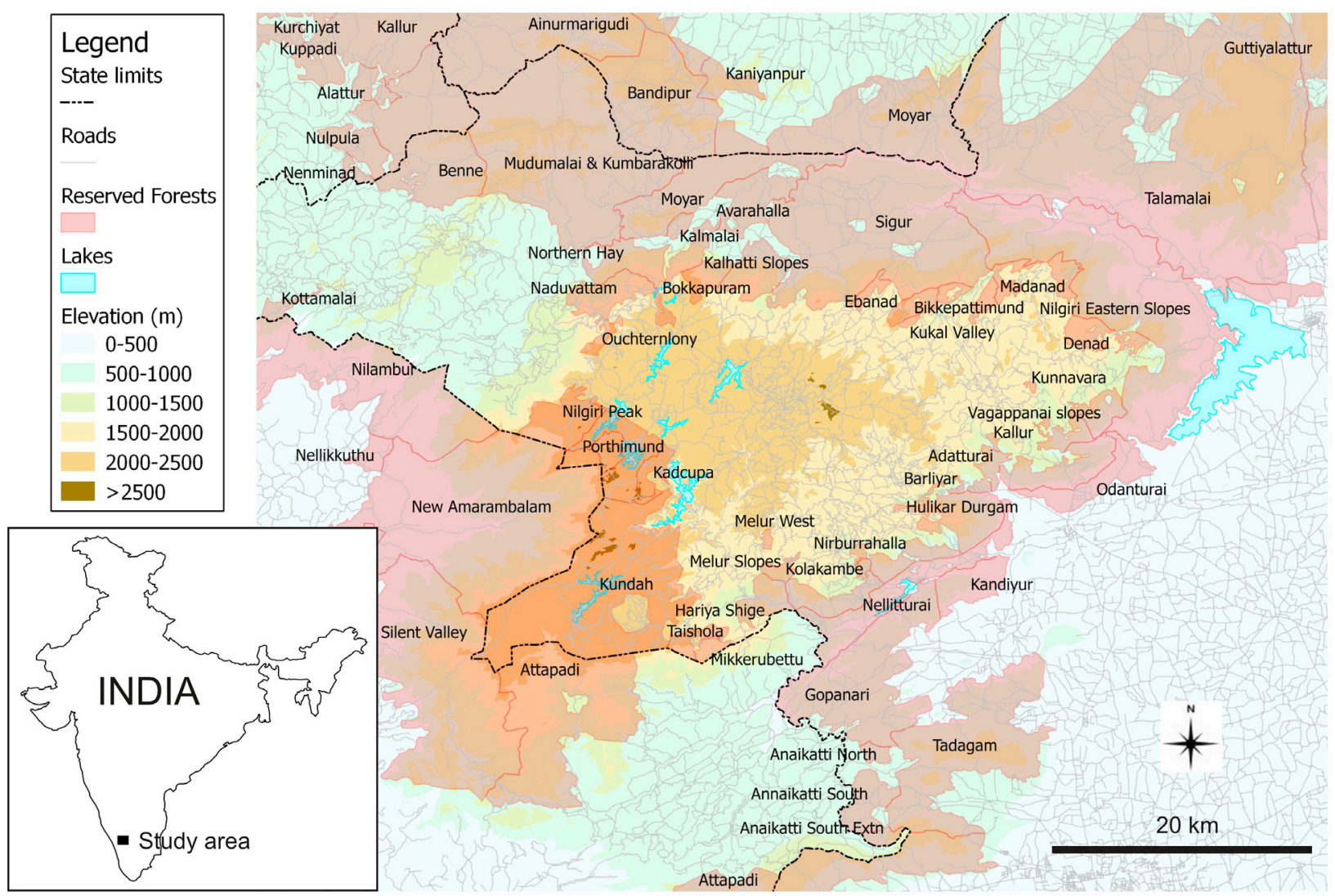

Image 2. Map of the reserved forests of the study area according to Prabhakar \& Pascal (1996)

the movement of elephants is blocked by three rows of penstocks, the trolley, and communication lines that run parallel to them. Animals on the slopes that want to cross over have to make a long detour by coming right down to the power house level at Singara, and skirt the Electricity Board camp before doing so. Then they meet the Singara-Masinagudi road connecting the two places. Elephants coming from the southern part of the Mudumalai Sanctuary also use this stretch to migrate to the Sigur range and the slopes.

On either side of the middle stretch of the Masinagudi-Singara road is a private forest. This forms part of the Singara estate. It is reported that this forest is under litigation [at the time of the study] and whether the land remains with the present owner or not, a corridor is necessary here. Land for such a corridor is more easily set apart and the corridor set up before the process of development begins.

It is recommended that a $600-800 \mathrm{~m}$ wide corridor connecting Kalmalai Reserved Forest and Singara Reserved Forest across the Masinagudi-Singara road between 3 and $4 \mathrm{~km}$ (from Masinagudi between the bridge over the channel and the Singara estate fence marking the new planting) be set up.

\section{Mavinhalla Revenue Forests}

On either side of the Sigur River there are reserved forests. On the west is the Mudumalai Sanctuary and Singara Reserved Forest, and on the east is Sigur Reserved Forest which connects the Talamalai plateau and the range of hills beyond. The reserved forests are contiguous below Chemmanatham and the slope above the Sigur bridge. However for a distance of 6 $\mathrm{km}$ both above and below Mavinhalla lands (cultivated and fallow), cattle pens and the Mavinhalla hamlet itself obstruct the passage of elephants, if a stretch of revenue forests south of Mavinhalla is not taken into account. This stretch of revenue forests serves as a corridor between the reserved forests on either side.

It is recommended that the revenue forests comprising revenue survey nos. $98,107,109,115$, and 246/1 of Masinagudi Village be converted to a reserved forest. Should it be considered very necessary, part of the survey fields on the northern end of the proposed corridor (close to Mavinhalla and the highway) may be excluded to be put to other uses. 


\section{$\underline{\text { 3. Masinagudi-Thengamarada road }}$}

Between Masinagudi and Sirur there is already a road which is about $20 \mathrm{~km}$ long. Of this, $5 \mathrm{~km}$ is a road of the Highways Department, and the rest is a metalled road maintained by the Forest Department. There is a proposal to upgrade this road and connect it to Thengamarada and take it on from there to Bhavanisagar and connect it to the SathyamangalamMettupalayam highway. The road will soon become a two lane highway. Branch roads are proposed to be laid to Hallimoyar and Kallampalayam. Work is already in progress and in 2 years' time the road is expected to be ready for traffic. This is a prime wilderness area rich in wildlife which has remained undisturbed so far. This road will traverse and cut across elephant migration paths in several places.

It is recommended that strict vigil be exercised to prevent exploitation to the detriment of wildlife.

\section{South and southeastern slopes}

On the south and south-eastern slopes of the Nilgiri hills, forests extend from Attapadi in Kerala to the west to Bhavanisagar in the east. Forests cover the base of the mountain and extend into the plains, varying in depth. Forest cover on the Tamil Nadu side is continuous, except for the ghat roads (mountain roads), a railway line, forest plantations, and the Kundah hydro-electric works at the lower levels, tea and coffee plantations, and villages interspersed among the forests at the higher elevations. Elephants are confined to the lower levels except for crop and jackfruit raiding forays into plantations higher up. The two main ghat roads, namely the Coonoor and Kotagiri ghat roads, the heavy traffic that they carry, the steep cuttings that have been made for laying roads, and the occupation of the land on either side of the road, are the main obstacles for movement of elephants.

\section{Kunjapanai Corridors}

The village of Kunjapanai on the Mettupalayam ghat road is located about half way between Kotagiri and Mettupalayam at an elevation of 1,200m. Elephants, mostly solitary or in small herds, frequent this area particularly during the jackfruit season. Elephants come from the forest below, the plantations, and the forests east of the road. They cross the road above and below Kunjapanai. This does not happen frequently; when they do it is usually very late at night. Below
Kunjapanai the steep slope and the road have made it difficult for elephants to move from one side of the road to the other.

It is recommended that either side of Kunjapanai, particularly the road-side land, is kept free of obstructions for the movement of elephants.

\section{Mettupalayam-Kotagiri ghat road}

The road is the second important link to the hills from the south. It traverses a stretch of scrub jungle which is part of the reserved forest in the plains. On the mountain slope steep road cuttings make it difficult for the animals to cross. Therefore the bases of the hills and the forests in the plains have to be kept clear of obstruction. The scrub east of the road at the lower (Mettupalayam) end has been cleared, and an experimental forest research station of the Tamil Nadu Agricultural Institute has come up. It is fenced in and acts as a barrier to animals. There is an explosives store on the west. Other such obstructions might come up along this road.

It is recommended that a $1 \mathrm{~km}$ stretch of the reserved forests on either side of the MettupalayamKotagiri road between 4.2 and $5.2 \mathrm{~km}$ (distance from Mettupalayam) be left free of obstruction.

\section{Mettupalayam-Coonoor ghat road: the Kallar corridor}

The Mettupalayam-Coonoor ghat road runs up the Hullical Valley. The ghat road is the main highway to the hills and starts its ascent at the $25^{\text {th }} \mathrm{km}$ from Mettupalayam. On either side of the road from the bottom up to Burliar are reserved forests composed of scrub and mixed jungle. The jungle on the east of the road extends up to Bhavanisagar and beyond on the west side up to Mulli on the Tamil Nadu-Kerala border. No movement is possible at higher elevation because of road cuttings, revetments, steepness of the slopes, fruit orchards and plantations. Passage is possible only at the start of the ascent. But at present, it is cut off because of the road itself, areca plantations and fields, not to mention heavy traffic. But traffic tapers off at night. In spite of these conditions elephants come as close as $100 \mathrm{~m}$ to the road, and there are reports of occasional elephant crossings at the $1^{\text {st }}$ hairpin bend ( $25^{\text {th }} \mathrm{km}$ stone). The Coonoor River and the Kallar River, which are only a short distance away, are frequently used by elephants. If access is to be provided in the shape of a corridor, elephants and Gaur 
(Bos gaurus) will make use of it.

It is recommended that:

a. A corridor about $100-150 \mathrm{~m}$ in width at and immediately below the first hairpin bend be set up to connect the reserved forests on either side.

b. For this purpose private land needs to be acquired. Some land leased by the Government across the Coonoor River may be resumed (such area to be acquired may not be more than 10 to 12 hectares in extent).

c. Plantations below the corridor should be fenced with a sturdy stone wall at Government cost to prevent migrating elephants from straying into plantations and causing damage.

d. The fence should be inspected periodically and maintained.

e. Some gaps should be left in the revetment supporting the first hairpin bend and steps/slopes taken to facilitate easy passage of elephants.

\section{Pillur-Melur slopes and Bhavani River Valley}

Until recently, on the southern and southwestern slopes of the Nilgiri hills and the Bhavani River valley above and west of Mettupalayam, forests extended westward until they met the Attapadi Reserved Forest, which is contiguous to the Silent Valley Reserved Forest. Now forests remain only on the Tamil Nadu side. On the Kerala side, the river valley has been converted into flourishing irrigation fields, and the lower slopes have been denuded and are being extensively grazed by domestic cattle. The slopes below Kinnakorai have been turned into fields even at the higher levels. The forests were the private properties of minor rajas who indiscriminately leased them out to cultivation. Had the Government taken action and made these into reserved forests this may not have happened.

The contiguity between the forests on the Tamil Nadu side and the Kerala side has been lost. Beyond the Tamil Nadu border, forests remain only in Attapadi and no movement of elephants between the forests on the two sides is possible. The few elephant herds on the Tamil Nadu side can move up to Manar and Pegumbahalla on the Karamadai-Kundah road (and a little distance up to the border) and not beyond. Even on the Tamil Nadu side elephant movement is hindered by power houses no. 3 and 4 of the Kundah hydroelectric scheme, the Pillur dam, large residential camps in three locations, the penstocks, network of roads, and cultivation. But these are not insurmountable obstacles and elephants have been moving around, up to the border and into the forests across the south of the Bhavani River. The restoration of these lost migration paths seems rather doubtful.

\section{The Gudalur Plateau}

The Gudalur Plateau is $1,000 \mathrm{~m}$ on average in elevation. To the west are the tropical evergreen forests of Nilambur, New Amarambalam, Silent Valley, and to the north and east are the moist mixed deciduous forests thinning into heavy scrub of Mudumalai and Bandipur. It was covered with forests (Fletcher 1911) and acted as a link between the forests of Kerala, Tamil Nadu, and Karnataka. The plateau became a center for mining, and tea and coffee planting in the nineteenth century. These were opened up in the place of forests. Mines were abandoned when they failed but the development of tea, coffee, and forest plantations continued. According to official records, the area occupied by plantations in the Gudalur Taluk is 1,200ha (approximately). Unofficially, the area is much larger due to encroachments. Now forests remain only within the Mudumalai Sanctuary limits, on the northwestern slopes (above Ouchterlony Valley), and in scattered reserves.

In 1969, the Tamil Nadu Tea Plantation Corporation Ltd. (TANTEA) moved into the area, and cleared the thickly wooded reserved forests around Cherangode, Cherambadi, and Nelliyalam, and planted tea to settle repatriates from Sri Lanka. New areas (some were grasslands) have been taken up in the past three years in Devala and Gudalur, and a further extent of 600ha has been added and expansion is in progress.

A distinct form of land tenure known as the janmum tenure, which applied to a third of the area, has been another unsettling factor. The Tamil Nadu Government sought to abolish the janmum tenure by legalization which is known as the "Gudalur Janmum Estates" (Abolition and Conversion into Riotwari) Act, 1969. Litigation over the enactment has been dragging on. Taking advantage of this unsettled situation, largescale to forcible occupation of janman [or janmun] lands has been taking place. It has become a free for all where profits were high, except for wildlife.

It would be a great advantage to wild elephants if the old links between Nilambur-New Amarambalam- 
Silent Valley and Mudumalai-Bandipur could be restored across the Gudalur plateau. But this is not a possibility. A new link may have to be forged. Even this is extremely difficult as there are many obstacles, the worst being the squatters who have reduced criminal trespass into a fine art. The squatter problem has become a political issue, most of the opposition parties and even the Government of Kerala oppose evictions.

Besides, getting elephants used to new migration paths in the form of corridors is not going to be easy. The slopes overlooking the Ouchterlony valley would have provided an ideal migration link, but it is cut-off at the Gudalur end of plantations and settlements. For a long time there has been no sign of elephants using these slopes for migration.

[In order to setup corridors], two routes have been suggested - one cutting right across the Gudalur plateau, and the other skirting the plateau (and partly through the Ootacamund Taluk) along its eastern border. Both start at different points in the Mudumalai Sanctuary and terminate at about the same area on the Tamil Nadu-Kerala border. It is desirable that both are attempted and at least sections are preserved for the day when public opinion demands a better deal for elephants.

8. The Benne (Mudumalai)-Needlerock - New Amarambalam corridor

[The full length of the proposed corridor is described in Table 1.] A corridor across TANTEA's new Gudalur and Devala divisions, stretching from the Kerala border to the Rockwood Reserve, is a long and vital link. A $200 \mathrm{~m}$ wide path could be in the form of a fuel reserve. High priority is accorded to this corridor because tree planting has just begun here so it is still possible to preserve this stretch. Even if it becomes impossible to set up a corridor for its whole length from New Amarambalam to Mudumalai, this TANTEA stretch alone would enable elephants to move at least up to Rockwood Reserve and Needle Rock as before.

As far as other big tea estates on the path are concerned, they may be allowed to retain the corridor land involved on the condition that the corridor land is developed as fuel reserve and allows the passage of elephants.

9. The Mudumalai-Ouchterlony valley Nilambur New Amarambalam corridor

[The full length of the proposed corridor is described in Table 2.] Solitary elephants do stray as far as Burnside Estate from the Kerala side, and the corridor is traced following their route. From below Burnside Estate the corridor will be almost wholly along the bed of the Pandey River and tributaries. The problem to overcome will be the squatters occupying the banks on either side. Passage through developed estates will be most difficult as there are lines [workers' quarters], buildings, etc. Where passage through estate

Table 1. The proposed Benne (Mudumalai)-Needlerock-New Amarambalam corridor

\begin{tabular}{|c|c|}
\hline Suggested waypoints & Distance \\
\hline Corridor $200 \mathrm{~m}$ wide from the Mudumalai Sanctuary on the Benne boundary on either side of the Benne-Mukatti forest road & \multirow{3}{*}{$2 \mathrm{~km}$} \\
\hline Passing through two small coffee estates until it reaches the Gudalur-Sultan's Battery road at Mukatti & \\
\hline $\begin{array}{l}\text { Across the Gudalur-Sultan's Battery road at Mukatti into the Gadsbrook Government Reserved Forest (eucalyptus plantation) which } \\
\text { can act as a corridor in itself }\end{array}$ & \\
\hline Beyond the Government reserve into the adjoining tea estate, across the border of the estate & $1.5 \mathrm{~km}$ \\
\hline $\begin{array}{l}\text { From the tea estate into the small private holdings mainly encroachments about } 1-2 \text { acres, each planted with paddy and jackfruit, } \\
\text { owned by } 15 \text { to } 20 \text { families }\end{array}$ & $3 \mathrm{~km}$ \\
\hline Across the Mukatti-Ponari road into a small tea estate the corridor skirting the Sussex division of the Woodbriar Group of tea estates & $1 \mathrm{~km}$ \\
\hline Across Sussex Division Reserve & $2 \mathrm{~km}$ \\
\hline Past the Devala-Nilakotai road and skirting the eastern flank of the Needlerock peak & $2 \mathrm{~km}$ \\
\hline Through Government Cinchona Department where a new plantation from Needlerock is destroying the natural forests & $3 \mathrm{~km}$ \\
\hline On the eastern side of Needlerock through the Devarshola Estate Reserve of Tea Estate India Ltd. & $4 \mathrm{~km}$ \\
\hline Across the new divisions (Devala and Gudalur) of TANTEA up to Marapalam on the Gudalur-Devala road & $4 \mathrm{~km}$ \\
\hline $\begin{array}{l}\text { Across the Gudalur-Devala road through TANTEA clearings to the Kerala border thus joining Mudumalai and Nilambur-New } \\
\text { Amarambalam Reserved Forests }\end{array}$ & $7 \mathrm{~km}$ \\
\hline
\end{tabular}


Table 2. The proposed Mudumalai-Ouchterlony Valley Nilambur-New Amarambalam corridor.

\begin{tabular}{|c|c|}
\hline Suggested waypoints & Distance \\
\hline $\begin{array}{l}\text { A corridor the width of } 200 \mathrm{~m} \text { starting from the south-east corner of Mudumalai Wildlife Sanctuary at the point where it crosses the } \\
\text { Moyar River below Thorapalli into Thodmoyar and along the river up to the southern boundary of Thodmoyar Estate through the } \\
\text { Northern Hay Reserved Forest }\end{array}$ & $3 \mathrm{~km}$ \\
\hline $\begin{array}{l}\text { Skirting Chikmoyar Estate border through the government cinchona plantation (the Naduvattam Reserved Forest being in possession } \\
\text { of the cinchona plantation) up to the point where it meets the Ooty-Gudalur road on the second hairpin bend from Gudalur, above } \\
\text { Silver Cloud Estate bungalow }\end{array}$ & $3 \mathrm{~km}$ \\
\hline Into the reserved forest above the Ooty-Gudalur road through the HasanBava Estate up to the third hairpin bend & $1 \mathrm{~km}$ \\
\hline $\begin{array}{l}\text { Across the road at the } 3^{\text {rd }} \text { hairpin bend across patta lands along the lower HasanBava Estate boundary (between the Manjushree } \\
\text { Estate, GudalurMalai Division new planting and lower Bava Estate new planting). Into the forest in the middle section of the eastern } \\
\text { slopes of GudalurMalai (Nellibetta Rock) }\end{array}$ & $2 \mathrm{~km}$ \\
\hline Up the eastern slopes (middle section) of the GudalurMalai then down the slopes & $2 \mathrm{~km}$ \\
\hline $\begin{array}{l}\text { Above the hill slope above the road until the Gudalur-Seaforth road is reached at a point between } 6 \text { and } 7 \mathrm{~km} \text { and below Burnside } \\
\text { Estate. It may be noted that the hill and slopes west of Gudalur are heavily encroached upon and there are estate lines. The passage } \\
\text { may be virtually impossible }\end{array}$ & $4 \mathrm{~km}$ \\
\hline $\begin{array}{l}\text { Skirting west of Burnside Estate and down the slopes until the Chundi River (Pandey River in maps) is reached } 100 \mathrm{~m} \text { on either } \\
\text { side of Chundi River through Ouchterlony Valley (Manjushree's New Hope) Estate into Seaforth Estate following the river until } \\
\text { Chunnambpallam is reached. It may be noted that the lands on either side of the river are heavily encroached }\end{array}$ & $3 \mathrm{~km}$ \\
\hline From Chunambalam along the Chundi River and other streams to the Peria Shola Tea Estate & $4 \mathrm{~km}$ \\
\hline Through Umbilimalai Estate along streams to Nilambur and New Amarambalam forest & $7 \mathrm{~km}$ \\
\hline
\end{tabular}

reserves becomes necessary, estates could develop fuel reserves.

\section{The upper plateau}

The Nilgiri mountains flatten out into a plateau roughly $900 \mathrm{~km}^{2}$ in area, above $1,500 \mathrm{~m}$ in elevation, with temperate conditions prevailing. Before the $1850 \mathrm{~s}$, the plateau consisted of mostly southern montane grasslands interspersed with southern subtropical hill forest (sholas) and scrub. A considerable area of grasslands and sholas have disappeared yielding place to plantations. This worsened due to the increasing size of towns and encroachments on Government land. Only the southwest parts of the plateau retain some of the original Nilgiri habitat. In recent years elephants were recorded with higher frequency, and this may be because of degradation of their habitats at the lower elevation.

There are three routes up the slopes to Upper Bhavani from the Attapadi-Silent Valley-New Amarambalam forests. One route is up the Galisi-Todiki slope skirting the Korakundah Estate, the second is up the Bhavanipuzha-Bison swamp slope, and the third is the Sispara bridle path through the Sispara pass [corridor 10]. Only small elephant herds are regular visitors. As more pressure builds up at lower elevations, larger herds are expected to come to the plateau. This should be encouraged [because this area might function as a refuge].

At present there are no impediments to elephants roaming over this entire area except for the upper Bhavani dam water spread. However, there is a proposal to build dams that might be obstacles across the path of elephants. There is a proposal to mine bauxite in the range of hills at Lakkidi (eastern end of upper Bhavani) to feed Malco's aluminium factory at Mettur. [This mining project has not been implemented so far.]

It is recommended that:

a. It is important that the Upper Bhavani country should continue to remain a wilderness area.

b. The proposal of the electricity board to build further dams in this area should be abandoned.

c. The bauxite mining proposal at Lakkidi should also be given up.

\section{CONCLUSION}

[It emerges from this work that elephant habitat in coastal areas of Kerala (Silent Valley, Attapadi) are isolated from inland habitats ranging from Nagarhole to Mudumalai to Bhavanisagar. Consequently, rainforest habitats are now isolated from drier type of forests. 
And elephants can no more circle the Nilgiris, as they probably used to do, to find better feeding grounds. However, this state of affairs should not prevent the search for solutions. Forging new corridors, reshaping boundaries between village lands and reserved forests in order to prevent conflicts with elephants, remains a priority.]

The considerations that weighed uppermost when making recommendations was that they should be pragmatic and capable of implementation. Care was taken not to propose any grandiose schemes. The recommendations are modest and should be workable. For the success of projects of this nature it is essential that local sympathies are not alienated. The cooperation and support of local people should be sought and obtained.

Lines of action and priorities have been indicated. Naturally the recommendations vary to suit the local conditions. While some require positive action, in the case of others all that is required is a safeguard that the prevailing conditions are not disturbed. Of course, the most important requirement is enthusiasm on the part of the concerned authorities, and the political will to put the recommendations into effect.

\section{REFERENCES}

Champion, H. \& S. Seth (1968). A Revised Survey of The Forest Types of India. Government of India Press, xxvii+404pp.

Davidar, E.R.C. (1978). Distribution and status of the Nilgiri Tahr Hemitragus hylocrius, 1975-1978. Journal of the Bombay Natural History Society 75: 815844.

Fletcher, F.W.F. (1911). Sport on the Nilgiris and in Wyanad. MacMillan, London, xvii+455pp.

GRASS Development Team (2010). Geographic Resources Analysis Support System (GRASS) Software, Version 6.4.0. Open Source Geospatial Foundation. http:// grass.osgeo.org.

Johnsingh, A.J.T. \& A.C. Williams (1999). Elephant corridors in India: lessons for other Elephant range countries. Oryx 33(3): 210-214.

Menon, V., V. Tiwari, S. Easa \& R. Sukumar (2005). Right of Passage: Elephant Corridors of India. Wildlife Trust of India, 287pp.

Prabhakar, R. \& J.-P. Pascal (1996). Nilgiri Biosphere Reserve Area. Vegetation and land use.Map 1:100,000. Centre for Ecological Sciences, Indian Institute of Science and the French Institute of Pondicherry, Pondicherry.

Quantum GIS Development Team (2011). Quantum GIS Geographic Information System. Open Source Geospatial Foundation Project. http://qgis.osgeo.org.

Santiapillai, C. \& P. Jackson (1990). The Asian Elephant: An Action Plan for Its Conservation. IUCN, 80pp.

Tamil Nadu Forest Department (2009). Report of the Expert Committee Formed in Pursuance of the Direction of the Hon'ble High Court in W.P.N.10098/2008, $2762 \& 2839$ of 2009. Unpublished. http://www.forests.tn.nic.in/graphics/Expert Committee_Report.pdf, 98pp.

\section{Acknowledgements}

1981: We thank Mr. A.M. Mahmood Hussain IFS, Additional Chief Conservator of Forests, Tamil Nadu Forest Department, and Y.S. Kadakshamani IFS, DFO Coimbatore for their formal permission to work in Mudumalai and Coimbatore Reserved Forests. But for the enthusiasm of Mr. J.C. Daniel, Chairman, Asian Elephant Specialist Group, this study would not have been possible. We also thank him for meeting the expenditure incurred on the study. We owe a debt of gratitude to the planting community who helped and shared information. We thank Mr. B. Palaniappan, Group Manager, Woodbriar Estate Ltd., Mr. C. Ramachandra Rao, Group Manager, Manjushree Plantations, Ltd., Mr. V.A. Krishnan, Senior Manager, Kilkotagiri Estates, Mr. K. Madappa, Manager, Korakundah Estate, Mr. E. Luke, Manager, Periashola Estate, Mr. D.R.B. Tyman, Managing Director, Tea Estates India Ltd., and Mr. A. Arunachalam IFS, Managing Director, TANTEA. Mr. Jude Michael, Shikari Bokkan, and informant Mari of Sirur helped on the many treks. To those who are going to initiate action on this report and implement the recommendations we wish them success.

2011: We thank Dr. Ajay Desai (Co-Chair, Asian Elephant Specialist Group), Dr. Simon Hedges (Co-Chair, Asian Elephant Specialist Group), and Dr. Simon Stuart, Chair, IUCN Species Survival Commission, for their initial interest in this publication. Dr. Asad Rahmani (Director, BNHS) and Dr. Ajay Desai kindly granted us permission to utilise the draft and publish it. We thank the Journal of Threatened Taxa and in particular the Founder \& Chief Editor, Dr. Sanjay Molur, for their enlightened editorial policy, and an anonymous referee of the Journal of Threatened Taxa for constructive comments. Dr. S. Jayakumar, Department of Ecology and Environmental Sciences, Pondicherry University, kindly provided us the elevation map of the region.

Author Details: The late E.R.C. DAVIDAR was a lawyer by profession and a conservationist. $\mathrm{He}$ pioneered studies on the Nilgiri tahr, elephant corridors, the dhole and the striped hyena. He established what may be the first ever private reserve in India and has authored a book on the recent ecological history of the Nilgiris.

Peter Davidar holds a MPhil in Wildlife Biology. $\mathrm{He}$ has undertaken surveys on elephant corridors and is presently a trustee of the Sigur Nature Trust, a private wildlife corridor. $\mathrm{He}$ is interested in wildlife photography.

PRIYA DAVIDAR is a professor of ecology at the Pondicherry University. She teaches conservation biology and behavior. Her research interests span over the fields of biogeography, biodiversity, pollination ecology and conservation.

JEAN-PHILIPPE PUYRAVAUD is an ecologist associated with ECOS, a trust for the conservation of nature. His main interest is habitat management for endangered species. He advises MSc and $\mathrm{PhD}$ students of the Pondicherry University in research methodology and landscape ecology.

Author Contribution: ERCD was the principal investigator of this project. He designed the study, conducted the field surveys and wrote a longer unpublished version of this paper for the Asian Elephant Specialist Group of the IUCN. $\mathrm{PeD}$ assisted in the field survey. PrD assisted with editorial work of the first version and helped revise the abridged version of the paper. J-PP revised and edited this abridged version of the paper, and prepared the maps. 